\title{
Hydroacoustic resolution of small-scale vertical distribution in Baltic cod Gadus morhua - habitat choice and limits during spawning
}

\author{
Matthias Schaber ${ }^{1, *}$, Hans-Harald Hinrichsen ${ }^{1}$, Stefan Neuenfeldt ${ }^{2}$, Rüdiger Voss $^{3}$ \\ ${ }^{1}$ Leibniz Institute of Marine Sciences, Düsternbrooker Weg 20, 24105 Kiel, Germany \\ ${ }^{2}$ Technical University of Denmark, National Institute of Aquatic Resources, Charlottenlund Castle, Jaegersborg Allé 1 , \\ 2920 Charlottenlund, Denmark \\ ${ }^{3}$ Sustainable Fisheries, Department of Economy, University of Kiel, Wilhelm-Seelig-Platz 1, 24118 Kiel, Germany
}

\begin{abstract}
Highly stratified marine ecosystems with dynamic features such as fronts or clines in salinity, temperature, or oxygen concentration challenge an individual's ability to select suitable living conditions. Ultimately, environmental heterogeneity organizes the spatial distributions of populations and hence the spatial structure of the ecosystem. Our aim here is to present a method to resolve small-scale distribution on an individual level, as needed for the behaviorally-based prediction of habitat choice and limits. We focused on the small-scale vertical distribution of cod Gadus morhua L. in the Bornholm Basin, central Baltic Sea, during spawning time in 2 years with different vertical thermohaline and oxygen stratifications. Individual cod were identified by echotracking of real-time in situ hydroacoustic distribution data. In order to resolve and identify hydrographic preferences and limits, ambient parameters including temperature, salinity, and oxygen concentration as well as expected egg-survival probability were individually allocated to each fish. The vertical distribution of hydroacoustically identified fish was compared to data simultaneously recorded by data storage tags attached to cod. The results showed a clear influence of ambient salinity and oxygen concentration on the distribution pattern and distributional limitation of cod during spawning time, and also consistency of data storage tag-derived distribution patterns with those based on individual echotracking. We therefore consider this method to be a useful tool to analyze individual behavior and its implications for the population's spatial distribution in stratified environments.
\end{abstract}

KEY WORDS: Baltic Sea $\cdot$ Cod · Vertical distribution · Hydroacoustic tracking · Environmental parameters

Resale or republication not permitted without written consent of the publisher

\section{INTRODUCTION}

Much focus has recently been put on distributional and ecological characteristics of marine fish with special regards to habitat availability and habitat use (Austin 2002a, Morris \& Ball 2006). Spatially explicit conservation measures such as closed areas (Apostolaki et al. 2002) as well as the assessment of predator-prey overlap (Neuenfeldt 2002, Neuenfeldt \& Beyer 2003) necessitate measurements of individual fish occurrence in relation to biotic and abiotic environmental parameters during different conditions, e.g. feeding or spawning.
Scientific echosounders provide real-time in situ 3D field data (Massé \& Gerlotto 2003) containing quantitative information on density and size distributions of backscattering organisms (Towler et al. 2003). Consequently, hydroacoustic surveys have widely been applied to the analysis of fish abundance (see MacLennan \& Simmonds 1992), diurnal and shoaling dynamics (e.g. Fréon et al. 1996, Orlowski 1999, 2005, Nilsson et al. 2003), predation and avoidance behavior (e.g. Handegard \& Tjøstheim 2005, Kaartvedt et al. 2005) as well as distribution and habitat association (e.g. Lawson \& Rose 2000a,b, Robichaud \& Rose 2001, McKinstry et al. 
2005). However, analyses based on echosounder data are often hampered because the detection of individual targets is difficult, and if identification of individual fish is possible, allocation of echoes to a certain fish species is difficult. Therefore, corresponding trawl hauls must be carried out for species identification and abundance estimation, with the shortcoming that small-scale acoustic information collected from echosounders is transformed to the larger trawl scale, which often cannot resolve environmental gradients and, thus, distributional characteristics in sufficient detail.

In this paper we propose a novel method to overcome this problem by applying hydroacoustic fish track identification. To verify our method, we compared observed individual-based, small-scale vertical distribution patterns in relation to ambient hydrography to data from comparable hydrographic situations obtained from data storage tags (DSTs). Focus was put on cod Gadus morhua L. in the central Baltic Sea during the peak spawning season.

Due to the semi-enclosed brackish water system characteristic of the Baltic, a strong vertical stratification of temperature, salinity, and oxygen is established. A permanent halocline separates low saline water on the surface from high saline deep water. Below that halocline, salinity continuously increases, whereas oxygen concentration decreases due to stable vertical stratification. Renewal of bottom waters and, thus, improvement of hydrographic conditions is only achieved by major water intrusions from adjacent North Sea regions. These irregular inflow events are strongly dependent on atmospheric forcing conditions (Matthäus \& Franck 1992, Matthäus \& Schinke 1994, Fonselius \& Valderrama 2003).

Cod reproduction in the central and eastern Baltic Sea is limited to the deep basins, as a minimum salinity of 11 ppt is required for fertilization success and neutral buoyancy of eggs (Westin \& Nissling 1991). Peak abundance of cod eggs occurs in the region of the halocline, with some quantities of viable eggs in the more saline deep layer, depending on oxygen levels (Kändler 1944, Wieland \& Jarre-Teichmann 1997). However, due to a lack of regular major inflow events, oxygen concentrations in these layers may often be too low for cod eggs to survive (Wieland et al. 1994). Oxygen concentration has a nonlinear effect on egg mortality. Ambient oxygen-related egg survival (OES) increases markedly above $2 \mathrm{ml} \mathrm{l}^{-1}$ oxygen concentration with $50 \%$ viable hatch at $4 \mathrm{ml} \mathrm{l}^{-1}$ (Köster et al. 2005).
We studied the vertical distribution of cod in their spawning environment in the Bornholm Basin during spawning time in 2 years with contrasting abiotic (inflow versus stagnation) conditions. Distributional characteristics were derived from single fish identified and tracked by hydroacoustic measurements. These individual-based, small-scale vertical distribution patterns of cod were related to ambient hydrography and ambient OES. Vertical distributions derived from electronically tagged individuals for the same specific period were used for verification of the echotracking.

\section{MATERIALS AND METHODS}

Hydroacoustics. Hydroacoustic data were continuously recorded during day- and nighttime on 2 research cruises of RV 'Alkor' in the central Baltic Sea in August 2003 and July/August 2005. Data sampling was carried out on a regular station grid (Fig. 1) used for measuring corresponding ambient hydrographic and biological parameters. A Simrad hull-mounted split-beam transducer ES38-B (beam width $6.86^{\circ}$ along and $6.80^{\circ}$ athwart) and a Simrad scientific Echosounder EK60 operated at $38 \mathrm{kHz}$ by Simrad ER60Software were used for collection of data. The echosounder and transducer had been calibrated with a $60 \mathrm{~mm}$ copper sphere prior to the survey according to

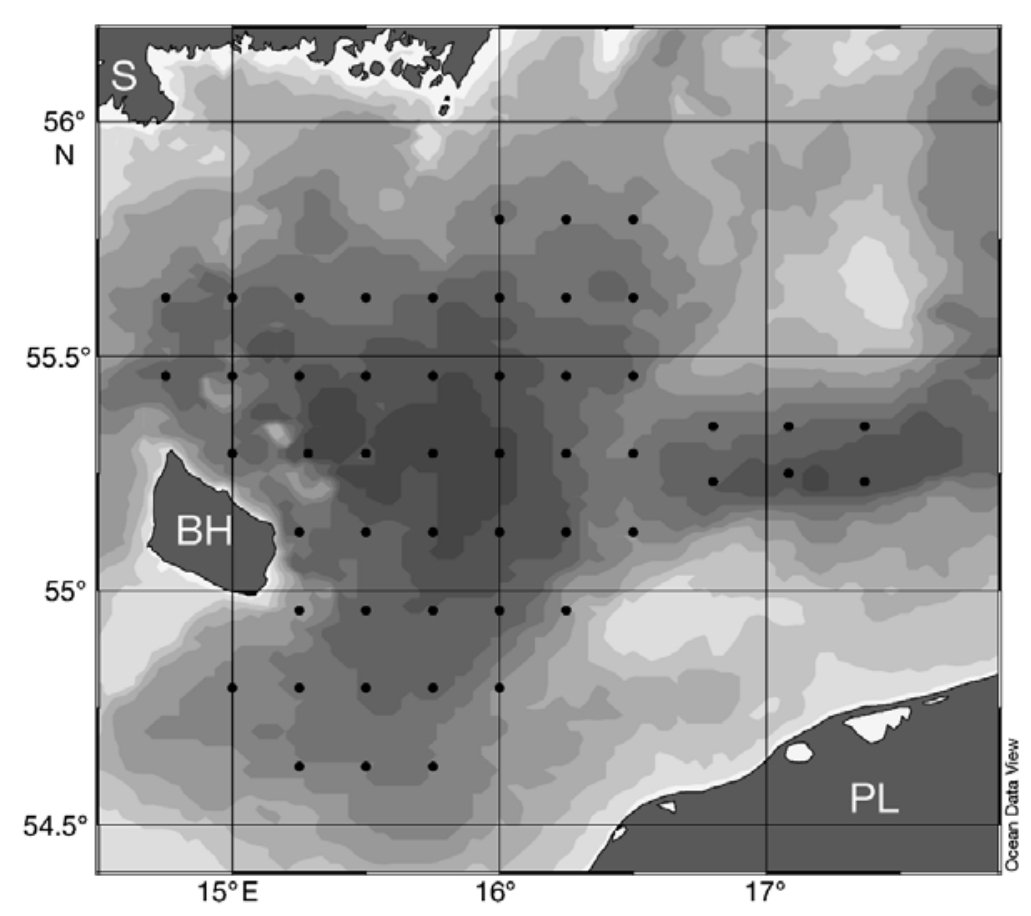

Fig. 1. Station grid used for measuring hydrographic and biological parameters in August 2003 and July/August 2005 (BH: Bornholm, Denmark; S: Sweden, PL: Poland). Map generated with Ocean Data View; http://odv.awi.de/ 
the standard method described by Foote et al. (1986) and ICES (2001). Ambient sound speed was calculated from temperature and salinity recorded and applied in echosounder settings during measurements. Transducer settings differed in the 2003 and 2005 cruises. In August 2003, the focus of echorecordings was on pelagic clupeid schools, whereas a higher horizontal and vertical resolution was set in July/August 2005. A detailed list of settings applied in the respective cruises is given in Table 1.

Post-processing of data was performed using Echoview software (Sonardata 2004, www.echoview. com). Echo detection of the bottom topography was corrected when necessary. Noise signals and scattering layers as well as clupeid schools were marked in the echograms and excluded from further processing, i.e. analyzing for single target echoes. Echoes located within the upper $10 \mathrm{~m}$ of the water column were neglected due to possible origin from artificial turbulent effects caused by ship operation.

Single target echoes were identified by applying Echoview's single target detection operator. Therefore, the split-beam single target identification Method 2 based on target strength and angular position data was adopted. Thus, echoes scattered by single fish could be discerned from those scattered by shoals of fish. As target strength (TS) is a function of fish size (Foote 1987, Clay \& Castonguay 1996, Ehrenberg \& Torkelson 1996, Rose \& Porter 1996, McQuinn \& Winger 2003), a threshold of $-50 \mathrm{~dB}$ was set for single cod identification in order to cover the size range derived from corresponding fishery hauls. The single target detection parameters used were: minimum normalized pulse length $=0.49$, maximum normalized pulse length $=$ 1.51, maximum beam compensation $=12.0 \mathrm{~dB}$.

The resulting single target echoes were processed using Echoview's target tracking algorithm, allowing the aggregation of single echoes to 1 track by allocating multiple consecutive echoes to a single fish and thus avoiding pseudo-replication of targets. The tracking algorithm chosen was based on range, angles, and time. Due to a mean vessel speed of 10 knots between stations, the horizontal range for target acceptance between single targets was set higher than vertical and lateral range, i.e. the minor (longitudinal) axis was allocated $50 \%$ weight in contrast to $30 \%$ weight for the major (transversal) axis. The minimum number of single targets required for an accepted fish track and the minimum number of pings in 1 track were set to 3 . This led to a reduction in the total number of fish tracks but also to an enhanced reliability of single tracks. In order to distinguish echotraces of densely aggregated multiple fish from interrupted echotraces left by a single fish, the fish tracks identified by the tracking
Table 1. Transducer settings used in cruises AL226 (August 2003) and AL262 (July/August 2005). TS: target strength

\begin{tabular}{|lcc|}
\hline & 2003 & 2005 \\
\hline Sample interval (s) & 0.000256 & 0.000128 \\
Frequency $(\mathrm{kHz})$ & 38 & 38 \\
Pulse length $(\mathrm{ms})$ & 1.024 & 0.512 \\
TS gain $(\mathrm{dB})$ & 26.22 & 25.91 \\
\hline
\end{tabular}

algorithm were manually edited and corrected when necessary. This was accomplished using angle echograms displaying along and athwart angular position data derived from the split-beam transducer. Both angular echograms and the single target echogram were synchronized and thus allowed the interpretation of the relative position of tracked targets in the beam and the identification of previously allocated fish tracks that needed to be split (originating from multiple fish) or merged (interrupted track from a single fish; A. M. Mueller, www. aquacoustics.com/ AngleEchograms.pdf).

Mean geographical position, mean depth and mean target strength of the single fish identified were then exported to Excel spreadsheets for further analysis. As the sample interval was lower (i.e. fewer pings on a horizontal scale) and the pulse duration was longer (i.e. lower vertical resolution) in 2003 than in 2005 (see Table 1), the number of resulting tracks was higher for 2005 ( $\mathrm{n}=5471$ ) than for 2003 ( $\mathrm{n}=1875)$.

Hydrography. Ambient vertically resolved hydrographic variables such as temperature, salinity, oxygen concentration, and saturation were recorded using an ADM-CTD probe deployed on the regular station grid in the Bornholm Basin (Fig. 1). These hydrographic parameters were then assigned to hydroacoustically located individual fish. The horizontal resolution of the hydrographic parameters can influence the prediction of the fish distribution. Thus, as a rule of thumb, the grid size should be fine enough to capture the appropriate horizontal mixing processes (e.g. smaller than the internal Rossby radius; Hinrichsen et al. 2002). Horizontal maps were constructed by interpolating the physical property data onto a model grid with $5 \mathrm{~km}$ horizontal resolution using objective analysis (Bretherton et al. 1976). An isotropic covariance function

$$
f(r)=\sigma^{2} \exp \left(-r^{2} / R^{2}\right)
$$

was used, where $R$ is the horizontal correlation scale $(25 \mathrm{~km}), \sigma^{2}$ is the variance, and $r$ is the distance between data points. It was assumed that the error variance due to measurement errors and small-scale noise amounted to $15 \%$ of the total variance of the fields, because in our field measurements the error 
variance did not exceed $15 \%$ of the total variance. Correlation length and variance were obtained from fitting the data to a Gaussian function. It was also assumed that the hydrographic field observations taken prior to the hydroacoustic surveys were quasi-synoptic. Further linear interpolation of data between model grid points was used to assign quasi-realistic ambient variables to each single fish identified.

Data storage tags. Data from echorecordings were compared to ambient hydrographic and distribution data obtained from tagged cod. The Star-Oddi CTD (conductivity, temperature, and depth) tags recorded ambient pressure (depth), temperature, and salinity every hour. Maximum recording period was set to 2 yr. Accuracy of the parameters after calibration was $\pm 0.5 \mathrm{ppt}$ for salinity, $\pm 0.1^{\circ} \mathrm{C}$ for temperature, and \pm 0.2 dbar for depth. Data extracted from recovered tags were then used to reconstruct migration routes of individual cod by geolocation using a hydrodynamic model of the Baltic Sea (Lehmann 1995). Hydrodynamic model runs could result in increasing uncertainties in the simulated physical property fields, and hence in the assignment of environmental properties to tagged individual fish. To overcome at least some of these problems, assimilation techniques were used to improve the output of the model simulations. In order to initialize and re-initialize the model, 3D distributions of temperature, salinity, and oxygen concentrations were taken from hydrographic surveys of Baltic cod covering different sub-areas of the Baltic Sea undertaken prior to the investigation periods. Both initialization and re-initialization of hydrographic properties prior to the beginning of the tagging period are an essential prerequisite to keep the uncertainty of the modeled data relatively low. Further improvement was achieved through additional (4 to 6) re-initializations of the modeled fields during the tagging period. During the surveys, the hydrographic property distributions in the western Baltic, the Arkona Basin, the Bornholm Basin, and the Stolpe Trench were recorded. Residuals obtained between physical parameters measured by the tags and the corresponding values generated by the model were used for quality control. Histograms for all parameters taken into consideration indicate that for all parameters (pressure, temperature, and salinity), $66 \%$ of the residuals were in the range of 0 to 0.5 . For detailed information on tags and methods applied, see Neuenfeldt et al. (2007). For comparison, only cod echoes and DST recordings below the halocline (salinity >9 ppt) were included ( $\mathrm{n}=111$ DST records in 2003 and $n=117$ DST records in 2005).

Cod habitat characterization. Distributional patterns of hydroacoustically identified cod in relation to ambient hydrography and available habitat frequencies were resolved. Relative available habitat distribution frequencies were calculated as relative frequency of a categorized parameter (temperature, salinity, oxygen concentration) based on numbers of all categories observed per parameter on the grid.

As distribution of cod was significantly limited to layers below the halocline, further results focused on distributional characteristics in habitats with a salinity higher than 9 ppt. This led to a reduction of single cod tracks to 1730 in 2003 and 5241 in 2005.

Data collection in both years took place in peak spawning time of eastern Baltic cod (Wieland et al. 2000). Therefore, cod distribution also was related to ambient OES. OES was calculated based on an oxygen-egg survival relationship by Köster et al. (2005) using a sigmoid function showing oxygen levels with a $50 \%$ relative viable hatch at $4 \mathrm{ml} \mathrm{l}^{-1}$. As a minimum salinity of $11 \mathrm{ppt}$ is required for fertilization success and neutral buoyancy of cod eggs (Westin \& Nissling 1991), OES was focused upon in layers with salinity $\geq 11$ ppt. This further reduced the absolute numbers of cod detections to 1584 (2003) and 5089 (2005).

To further identify and statistically evaluate preferred habitat of cod and environmental habitat limits, the total hydroacoustic transects were classified in horizontal and vertical strata (observation cells with a $10 \mathrm{~km}$ horizontal and $5 \mathrm{~m}$ vertical resolution). Quotient curves were derived from hydroacoustically obtained cod abundance data and individual environmental variables within each stratum. The ratio $\left(Q_{C}\right)$ of the percentage of total number of cod within each environmental parameter $\left(\% \operatorname{cod}_{c}\right)$ and the percentage frequency of occurrence of each environmental parameter (\%environmental parameter ${ }_{c}$ ) was calculated as

$$
\mathrm{Q}_{\mathrm{C}}=\% \operatorname{cod}_{\mathrm{C}} / \% \text { environmental } \text { parameter }_{\mathrm{C}}
$$

This analysis is based on the whole column below the halocline in each horizontal stratum with cod identified. Quotient values greater than 1 indicate positive selection of related categories, whereas quotient values less than 1 are considered to represent avoidance of those parameters (van der Lingen et al. 2001). Statistical evaluation was performed by applying the adapted R library 'Shachar' (developed by M. Bernal) that includes a randomization test estimating the $95 \%$ confidence limits for rejecting the null hypothesis of the observed quotient within a particular environmental category being obtained by pure chance alone.

To further isolate and statistically validate factors affecting cod abundance (CA) in the field, non-parametric regression models (i.e. generalized additive models, GAMs) were used (e.g. Porter et al. 2005, Dingsør et al. 2007). A GAM is a statistical model blending properties of multiple regressions (a special 
case of general linear model) with additive models. In a GAM, the parameter terms $b_{\mathrm{i}}$ and $x_{\mathrm{i}}$ of a multiple regression are replaced with functions $f\left(x_{i}\right)$; The functions $f\left(x_{\mathrm{i}}\right)$ are arbitrary and often nonparametric, thus providing the potential for better fits to data than other methods. A typical GAM might use a smoothing function such as a locally weighted mean for the $f\left(x_{\mathrm{i}}\right)$. Thus, the priority of GAMs is predictive ability.

The following physical environmental variables were determined for each observation cell and subsequently used as independent variables to explain adult cod abundance. (1) Latitude, longitude: for each observation cell, the mean geographical position was recorded, giving information about adult position in relation to the basin topography. (2) Ambient temperature, salinity, oxygen content: temperature profiles were measured on each CTD station and allocated to each cod identified. Mean temperature, salinity, and oxygen content were calculated for each observation cell to represent adult cod ambient conditions. (3) Vertical gradients in abiotic conditions: for each observation cell, the within-cell gradient of abiotic condions, i.e. the change in conditions over a $5 \mathrm{~m}$ vertical scale, was calculated, as organisms accumulate at clines (e.g. Morgan et al. 2005) or use gradients for orientation (Ferno et al. 1998). (4) Inflow/stagnation: hydrographic conditions in the Bornholm Basin are very different comparing post-inflow situations to years after a longer time of stagnation. In January 2003, a major Baltic inflow occurred, which dominated the hydrographic conditions in August 2003. After 2 further years of stagnation, the situation in summer 2005 can be seen as a typical stagnation scenario. Therefore, the yeareffect was included as a factor variable with 2 levels. (5) CA: for each observation cell, a CA of $n=0$ to 73 adult cod was identified by single-fish detection and tracking algorithms. As the dependant variable CA was not normally distributed, a fourth-root data transformation was applied. Afterwards no significant deviation from the normal distribution occurred (David et al.-test, p < 0.05; Lozán \& Kausch 1998).

All environmental factors were initially included as covariates in an additive GAM. The generalized cross validation (GCV; Wood 2000) was used as the criterion for model selection: all combinations of covariates were tested, potentially excluding non-significant $(\mathrm{p}>$ 0.05 ) covariates and minimizing the GCV. The GCV is a measure of predictive error of the model and thus takes into account not only the fit, but also the model complexity. It therefore does penalize excessively complex models as a result of greater prediction error. All analyses were conducted using $\mathrm{R}$ software (version 2.2.0, www.r-project.org), specifically the package 'mgCv.'

\section{RESULTS}

\section{Hydrography}

The hydrography in deeper water areas observed during the August cruise in 2003 was primarily determined by a strong inflow event in January 2003 (Fig. 2a). This major Baltic inflow entirely replenished the old oxygen-depleted water masses below the permanent halocline. Salinities at the bottom exceeded 18 ppt. Oxygen concentrations near and below the halocline remained at high levels $\left(6 \mathrm{ml} \mathrm{l}^{-1}\right)$ until March 2003 (Hinrichsen et al. 2007). From our cruise data it is obvious that by August these oxygen concentrations quickly decreased to $3 \mathrm{ml} \mathrm{l}^{-1}$ at the bottom.

In summer 2005, after a lack of further inflows, the hydrographic conditions had deteriorated (Fig. 2b). Hydrographic measurements identified the permanent halocline in the Bornholm Basin in the depth range 55 to $60 \mathrm{~m}$ increasing from east to west. Within the deep water area, oxygen values were below $2 \mathrm{ml} \mathrm{l}^{-1}$ with temperatures around $6^{\circ} \mathrm{C}$ and salinities not exceeding $17 \mathrm{ppt}$. Although there was an indication of a new inflow of highly saline water that had entered the Bornholm Basin in January 2005, the oxygen conditions in the deep part of the Bornholm Basin had only slightly improved.

\section{Vertical distribution of cod in relation to mean hydrography}

There was a marked difference in the vertical distribution pattern of identified echoes between August 2003 and July/August 2005 (Fig. 2). However, most of the echoes were situated below the halocline in both years. Corresponding fishery hauls and DST recordings (see next section) showed that there were no cod above the halocline. Thus, echoes above the halocline were considered non-cod. In 2003, cod showed a broad distribution below the halocline. Comparison to mean hydrography showed that the vertical distribution of cod was strongly linked to ambient hydrographic parameters. Salinity seemed to constitute the upper distributional limit, whereas oxygen concentration was the limiting factor in deeper water. In 2003, the whole water column was well oxygenated, with average oxygen levels still close to $3 \mathrm{ml} \mathrm{l}^{-1}$ down to the seafloor. Therefore, no distinct vertical limitation as well as a relatively even distribution of cod below the halocline was obvious. There was no clear effect of temperature on fish distribution. In 2005, upper distributional limits also were set by the halocline with $95 \%$ of echoes identified in salinities $>10$ ppt $(92 \%>11 \mathrm{ppt})$. With regard to oxy- 


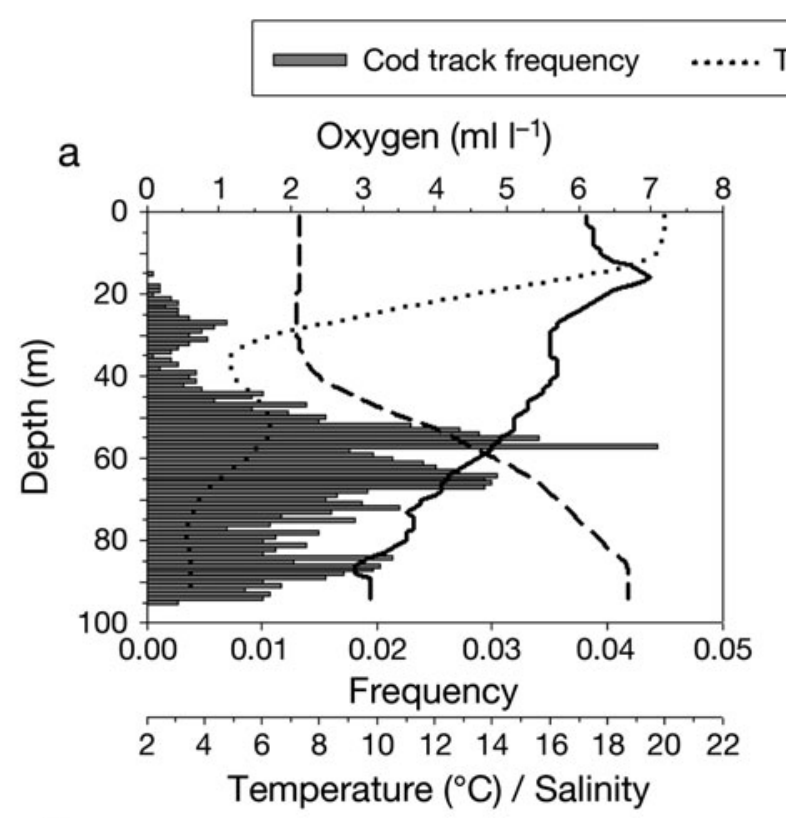

C

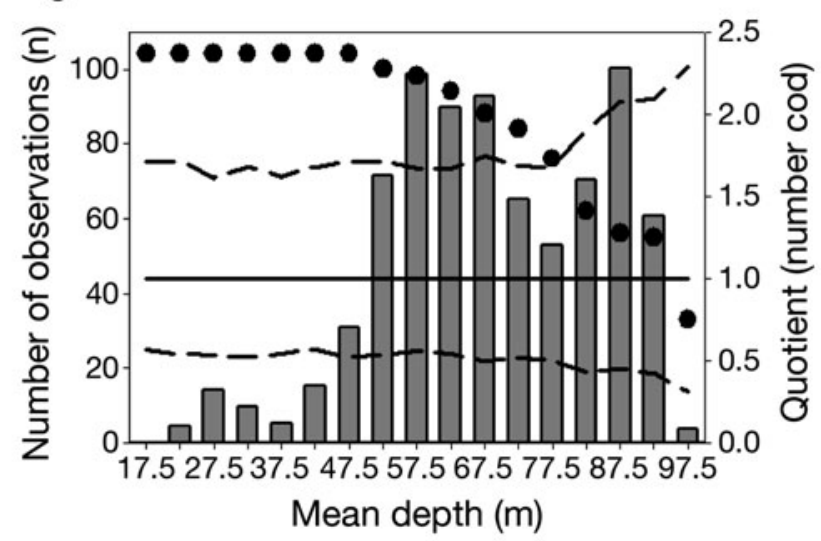

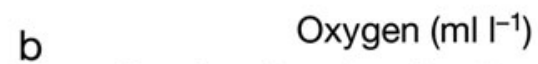

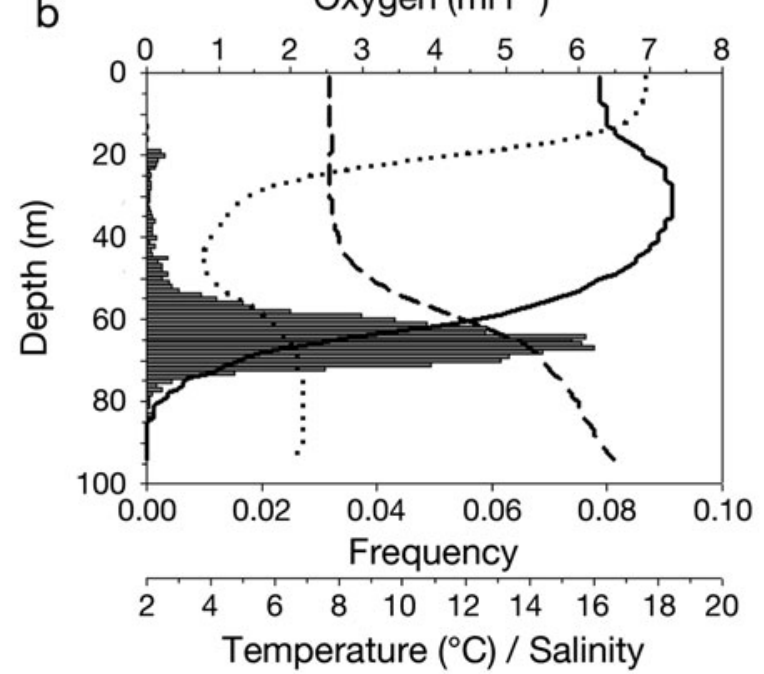

d

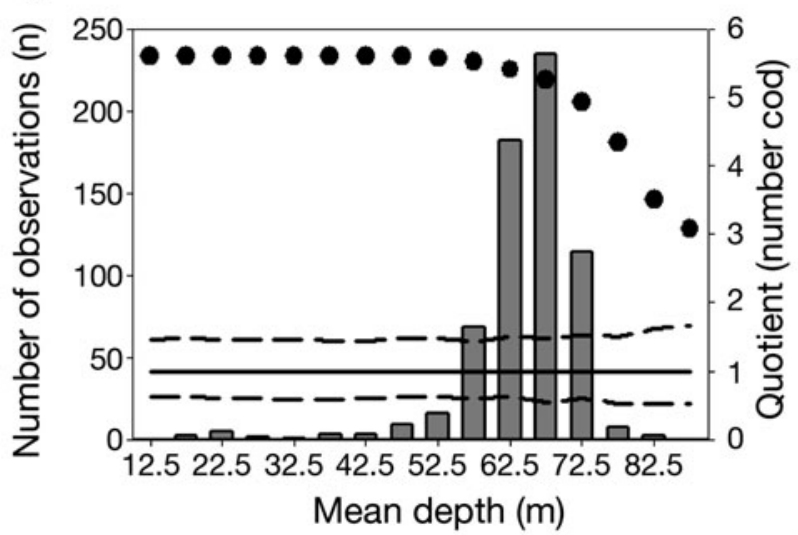

Fig. 2. Gadus morhua. Depth distribution of single fish echoes in August 2003 (a, $\mathrm{c}_{;} \mathrm{n}=1875$ ) and July/August 2005 (b,d; $\mathrm{n}=5471$ ) as derived from echotracking. $(\mathrm{a}, \mathrm{b})$ Distribution in relation to mean ambient hydrography. (c,d) Quotient rule analysis; dots: number of observations of corresponding abiotic parameter; bars: single fish quotient curve; dashed lines: $95 \%$ confidence interval; solid line: quotient value 1 (marking random selection of habitat)

gen, a clear depletion due to lack of inflow was measured in deeper waters. Oxygen concentration was below $1 \mathrm{ml} \mathrm{l}^{-1}$ at $73 \mathrm{~m}$ depth, and from $84 \mathrm{~m}$ downwards, no oxygen was detectable. Fish distribution markedly followed the oxycline with only a very small fraction $(0.4 \%)$ of identified echoes being distributed below $73 \mathrm{~m}$. As in 2003, there was no clear effect of temperature on vertical cod distribution. Quotient analysis showed a significant avoidance of water layers shallower than $45 \mathrm{~m}$ and a clear preference for layers below the halocline (significant between 55 and $70 \mathrm{~m}$ ) in 2003, whereas in 2005, a clear and significant avoidance of layers above $55 \mathrm{~m}$ and below $75 \mathrm{~m}$ could be shown. Instead, cod significantly preferred depths between 55 and $75 \mathrm{~m}$.

\section{Comparison of echodata and tags}

With the exception of 1 record in July 2005, in both years observed there were no records from DSTs attached to cod from above the halocline, i.e. all tagged cod were found almost exclusively below the halocline during the observation period.

In August 2003, cod echoes below the halocline ( $\mathrm{n}=$ 1730) were distributed between 41 and $95 \mathrm{~m}$ with a distribution maximum at $57 \mathrm{~m}$ (Fig. 3a). Two local distribution maxima were found in layers between 64-67 $\mathrm{m}$ and 86-87 $\mathrm{m}$ (>2 to >3\% in each depth layer). Data from DSTs revealed a distribution between 58 and $95 \mathrm{~m}$ during the period observed. Over $95 \%$ of observations ( $\mathrm{n}=111$ ) were found between 60 and 
$75 \mathrm{~m}$ with local accumulation maxima at 64 and $73 \mathrm{~m}$ (9 to $11 \%$ ) and an absolute distribution maximum at $70 \mathrm{~m}(13 \%)$. Only 4 observations were recorded in water layers deeper than $77 \mathrm{~m}$.

In 2005 (Fig. 3b), cod echoes below the halocline were observed between 45 and $87 \mathrm{~m}(\mathrm{n}=5241)$. Most of the echoes (91\%) were situated between 57 and $72 \mathrm{~m}$ with a clear accumulation between 64 and $67 \mathrm{~m}$ (32\%) and a distribution maximum at $67 \mathrm{~m} \mathrm{(8 \% ).}$ Only $2 \%$ of all cod observed were situated below $73 \mathrm{~m}$. A comparison to data from DSTs $(\mathrm{n}=117)$ revealed a similar distribution pattern of tagged cod during the period observed. Tag depth recordings ranged from 36 to $73 \mathrm{~m}$. Approximately $90 \%$ of tagged cod were found in water layers below $60 \mathrm{~m}$. A clear aggregation maximum corresponding to hydroacoustic data was observed between 63 and $65 \mathrm{~m}(39 \%)$ as well as a decrease in relative frequency below $70 \mathrm{~m}$ depth.

\section{Habitat utilization}

Temperature

Observed habitat utilization below the halocline took place between 3.25 and $9.5^{\circ} \mathrm{C}$ in 2003 (Fig. 4a). More than $95 \%$ of cod observed were distributed in temperatures between 3.25 and $6.25^{\circ} \mathrm{C}$ with local maxima at 3.5 and $5.25^{\circ} \mathrm{C}$. Comparison to the frequency of available habitat in 2003 showed that cod did not use the whole temperature range available below the halocline. However, the temperature ranges with accumulations of cod were also present at higher frequencies in the available environment. Quotient analysis showed no clear pattern of prefer-

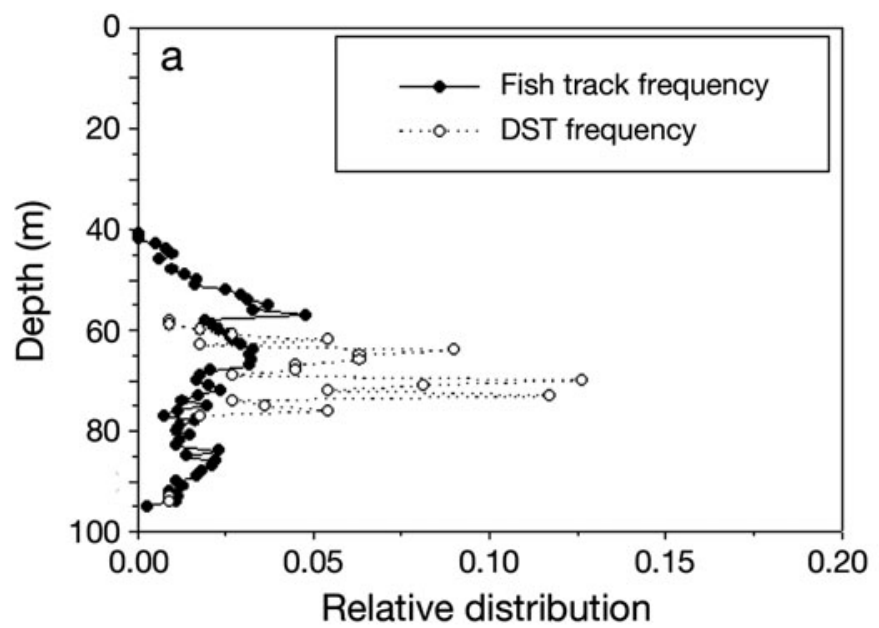

ence or avoidance. Only temperatures higher than $7^{\circ} \mathrm{C}$ were preferred, with preference becoming significant above $8^{\circ} \mathrm{C}$.

In August 2005, after 2 yr of stagnation, cod habitat utilization in relation to ambient temperature showed a different distribution pattern (Fig. 4b). Except for temperatures of 8.5 to $8.75^{\circ} \mathrm{C}$, the whole available temperature range below the halocline was used. However, clear accumulations at different temperatures were obvious: from 5 to $5.5^{\circ} \mathrm{C}(24 \%)$ and from 6 to $7^{\circ} \mathrm{C}(56 \%)$. Maximum abundance of cod was recorded at 6.5 to $6.75^{\circ} \mathrm{C}(17 \%)$. Available temperature habitat frequencies were almost evenly distributed below $6^{\circ} \mathrm{C}$, i.e. not explaining the accumulation of echoes at 5 to $5.5^{\circ} \mathrm{C}$ by habitat availability. However, the layers with the highest cod frequencies also showed the highest habitat frequencies. Quotient analysis showed general avoidance of temperatures lower than $5^{\circ} \mathrm{C}(\mathrm{p}<0.05)$ and a preference for higher temperatures.

\section{Salinity}

In 2003, cod were distributed throughout all observed salinity levels from the halocline downwards (Fig. 5a). There were distributional accumulations and local maxima in layers with a salinity of 12 to 13 ppt (20\%) and 18.75 to 19 ppt (8\%). Comparison of cod distribution with the relative frequency of available habitat revealed no clear trend. All salinity levels higher than 9 ppt were almost evenly present with only levels >17.5 ppt appearing less frequent. Quotient analysis showed a clear avoidance of salinity levels lower than 10.7 ppt ( $p<$ 0.05 ) and preference for layers with a salinity of

Fig. 3. Gadus morhua. Relative depth distribution below halocline (salinity $>9$ ) of echo tracks in comparison to depth distribution data obtained from data storage tags in $2003(\mathrm{a}, \mathrm{n}=1730 \mathrm{cod}$ and $\mathrm{n}=111$ tags $)$ and $2005(\mathrm{~b}, \mathrm{n}=5241 \mathrm{cod}$ and $\mathrm{n}=117$ tags) 
11.3 to 17.2 ppt. Preference for these salinity levels was not significant, as was the trend towards avoiding salinity levels $>17.2$ ppt.

In 2005, the cod distribution in relation to ambient salinity showed a stronger limitation of layers used compared to habitat availability (Fig. 5b). Most cod identified $(96 \%)$ were distributed in salinity levels between 11.25 and 14.5 ppt. No cod were observed in salinity levels higher than 15.25 ppt, although those were available as habitat. Quotient analysis revealed a clear and mostly significant avoidance of low salinities $(<11.5 \mathrm{ppt})$ as well as high salinities (>14.3 ppt). Salinity levels between 11.6 and 14.2 ppt were characterized as preferred habitat (12 to $14 \mathrm{ppt}_{\text {; }} \mathrm{p}<0.05$ ).
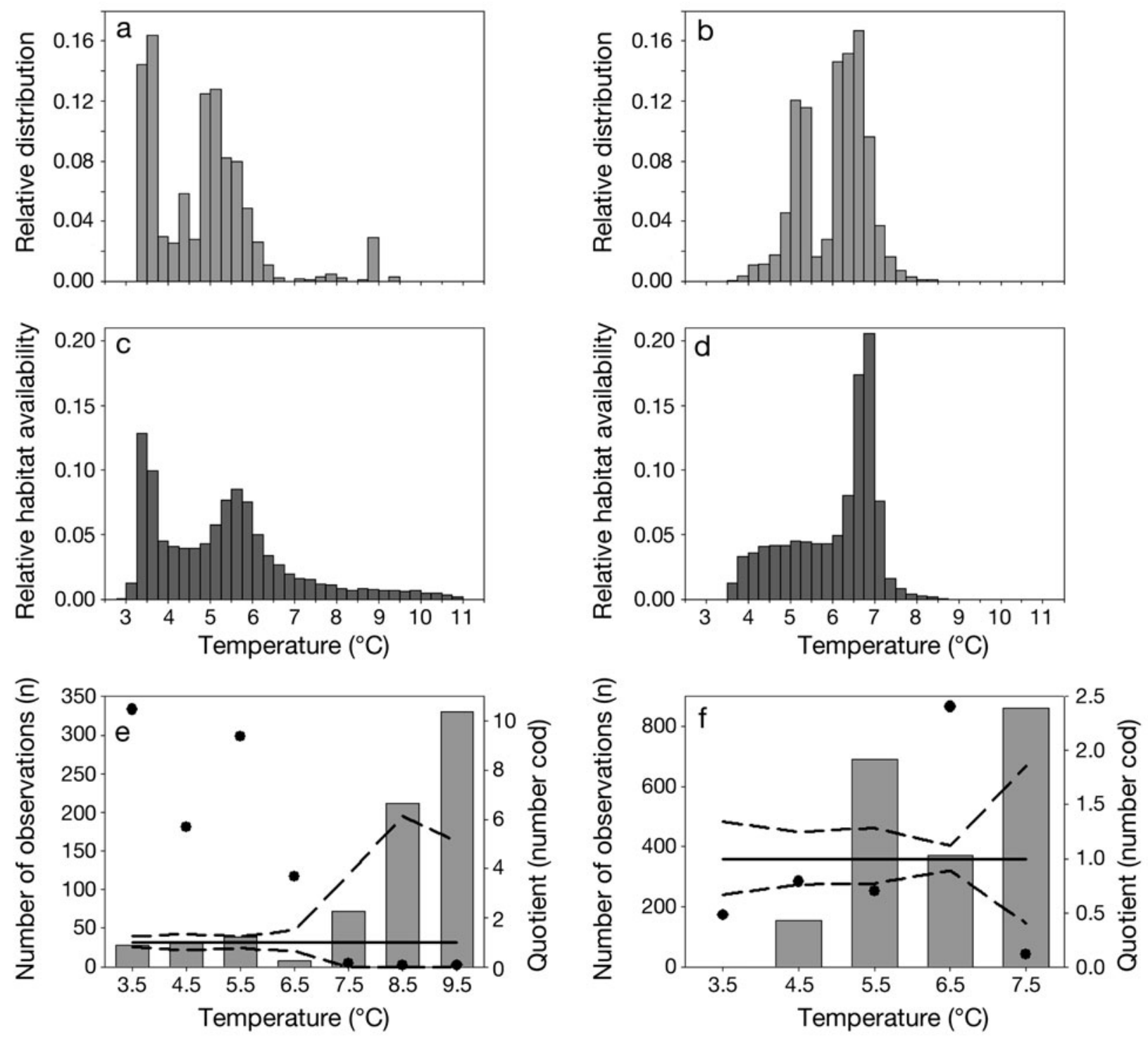

Fig. 4. Gadus morhua. Distribution of echoes below the halocline in August $2003\left(\mathrm{a}, \mathrm{c}, \mathrm{e}_{;} \mathrm{n}=1730\right)$ and July/August $2005(\mathrm{~b}, \mathrm{~d}, \mathrm{f} ; \mathrm{n}=$ $5241)$ in relation to $(\mathrm{a}, \mathrm{b})$ ambient temperature and $(\mathrm{c}, \mathrm{d})$ relative availability of habitat in both years. (e,f) Quotient rule analysis; dots: number of observations of corresponding abiotic parameter; bars: cod quotient curve; dashed lines: $95 \%$ confidence interval; solid line: quotient value 1 (marking random selection of habitat) 
In August 2005, cod were distributed in oxygen concentrations between 0 and $6.75 \mathrm{ml} \mathrm{l}^{-1}$ (Fig. 6b). The fraction of cod detected in layers with an oxygen concentration of less than $1 \mathrm{ml} \mathrm{l}^{-1}$ was very small. However, $38 \%$ of cod identified were found at low oxygen levels between 1 and $2.5 \mathrm{ml} \mathrm{l}^{-1}$. The preferred level of 3 to $3.5 \mathrm{ml} \mathrm{l}^{-1}$ only contributed $\sim 5 \%$ to the available habitat. Due to a clear oxygen depletion below the halocline, oxygen levels of 0 to 1 $\mathrm{ml} \mathrm{l}^{-1}$ were present to a large extent. Quotient analysis revealed a clear and significant avoidance of oxygen concentrations lower than $1.5 \mathrm{ml} \mathrm{l}^{-1}\left(<1.3 \mathrm{ml} \mathrm{l}^{-1}\right.$, $\mathrm{p}<0.05)$, whereas oxygen concentrations between $1.5 \mathrm{ml} \mathrm{l}^{-1}$ and $4.5 \mathrm{ml} \mathrm{l}^{-1}$ were positively selected.
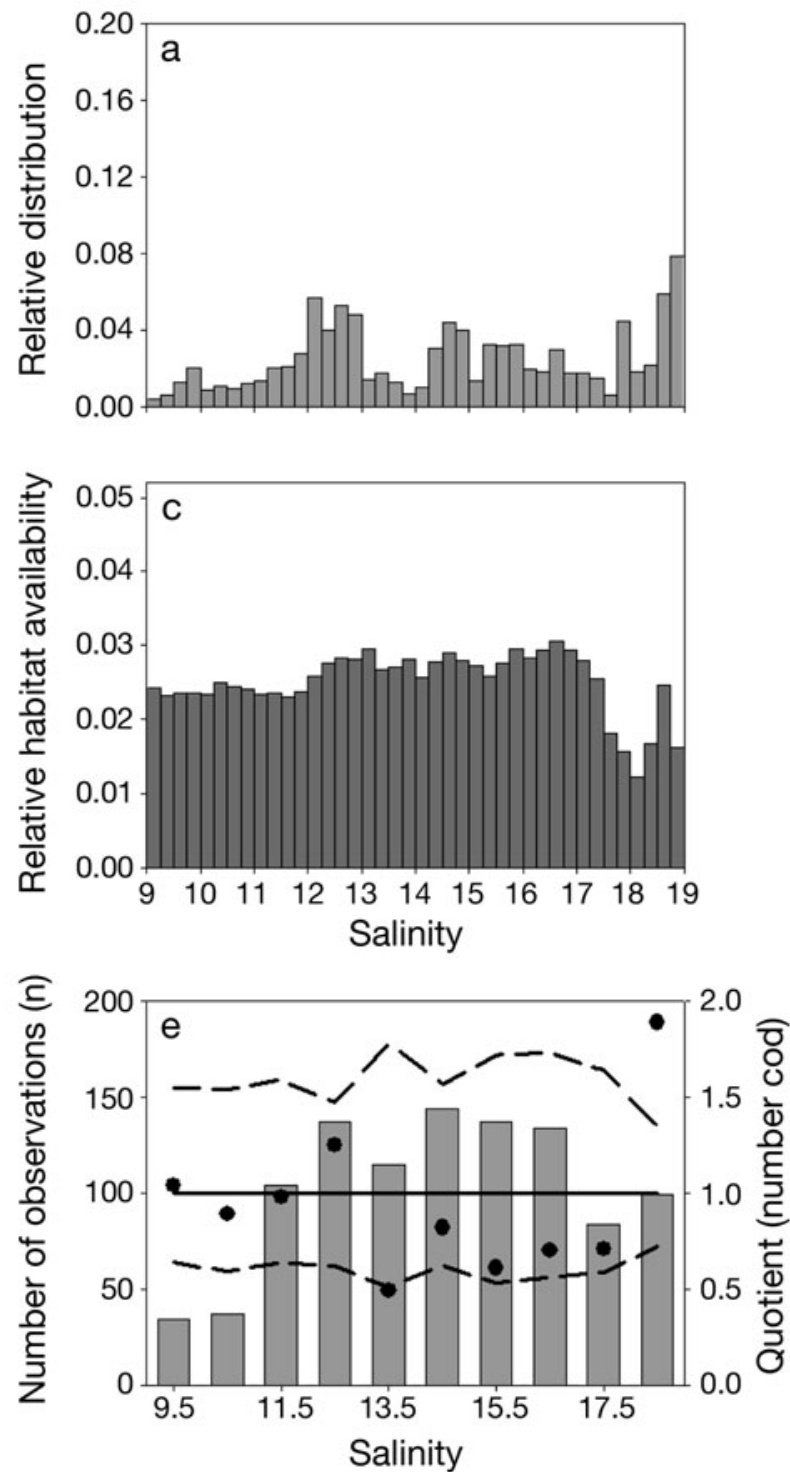

Higher concentrations were present at a low number of stations and were selected or avoided mostly randomly.

\section{Oxygen-related egg survival}

In 2003, cod were distributed in high saline (>11 ppt) layers with a calculated OES of 0 to 0.85 (Fig. 7a). Most of the cod $(67 \%)$ were situated in layers with OES of 0.15 to 0.5 , but a small proportion (10.1\%) were observed in regions with an OES of less than 0.1 . Available habitat showed egg survival probabilities of 0 to 0.95 . Only $0.6 \%$ of habitat available showed an OES of less than 0.1 .
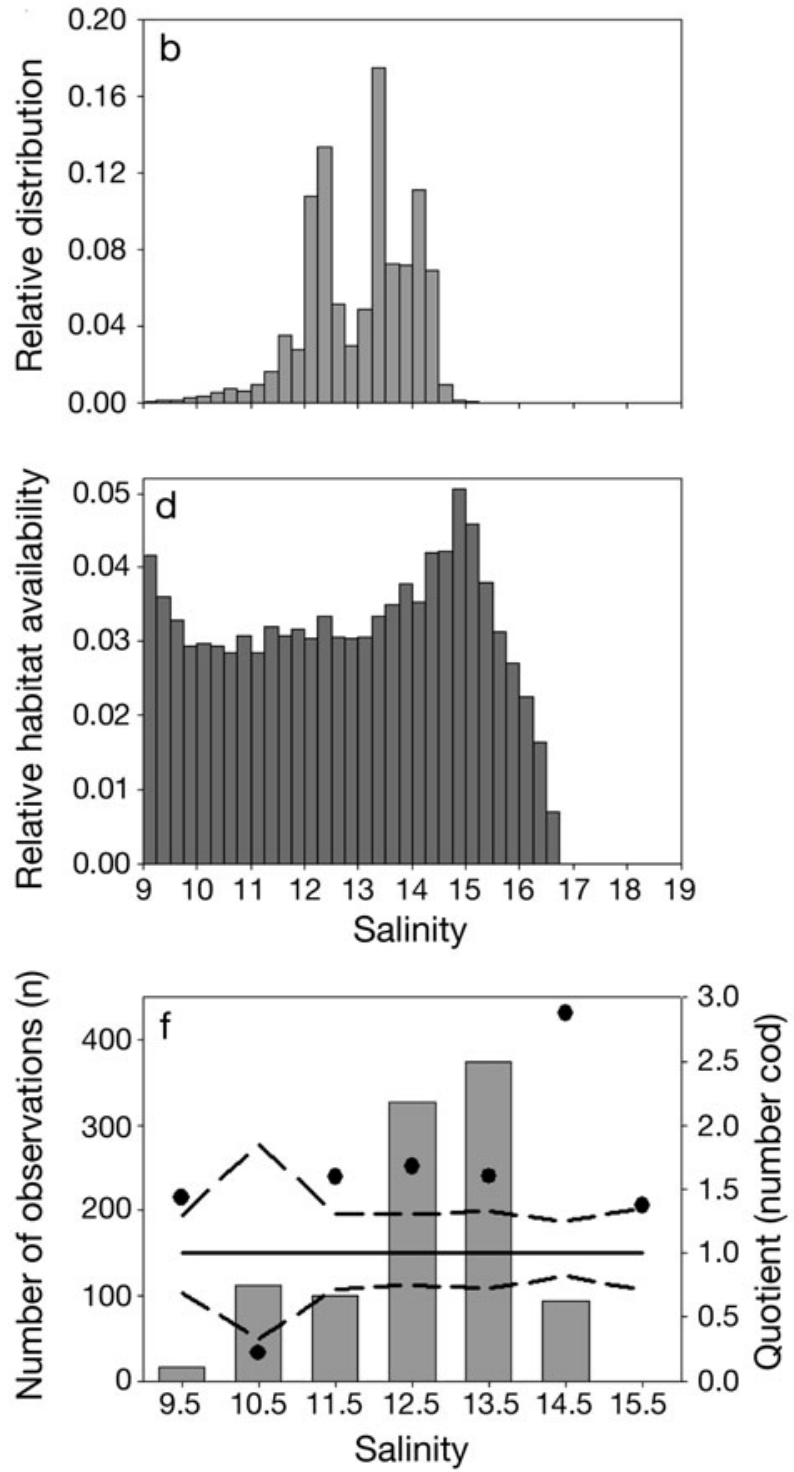

Fig. 5. Gadus morhua. Distribution of echoes below the halocline in August 2003 (a,c,e; n = 1730) and July/August 2005 (b,d,f; $\mathrm{n}=5241)$ in relation to $(\mathrm{a}, \mathrm{b})$ ambient salinity and $(\mathrm{c}, \mathrm{d})$ relative availability of habitat in both years. (e,f) Quotient rule analysis; dots: number of observations of corresponding abiotic parameter; bars: cod quotient curve; dotted lines: $95 \%$ confidence interval; solid line: quotient value 1 (marking random selection of habitat) 
In 2005 (Fig. 7b), cod were observed in water layers with a similar range of OES rates as in 2003 (0 to 0.75 ). However, in contrast to 2003, a significant fraction $(25 \%)$ was situated in water masses with an egg survival probability of $<0.05$. Available habitat was dominantly characterized by egg survival probabilities of 0 to 0.05 (49\%). Only $25 \%$ of ambient water was characterized by an OES $>0.5$. Quotient analysis for 2003 and 2005 showed a significant negative selection of habitat with an OES $<0.1$ in both years.

\section{GAM results}

According to the GAM, all inspected environmental factors had a significant $(\mathrm{p}<0.0001)$ effect on adult cod abundance. The GCV score was 0.53197, and the model explained $47.4 \%$ of the variance. The results from the quotient plot analysis with ambient temperature and, to a higher extent, ambient salinity and oxygen influencing cod habitat were statistically validated. The model results showed a negative effect of temperature below $8.5^{\circ} \mathrm{C}$ and a positive effect
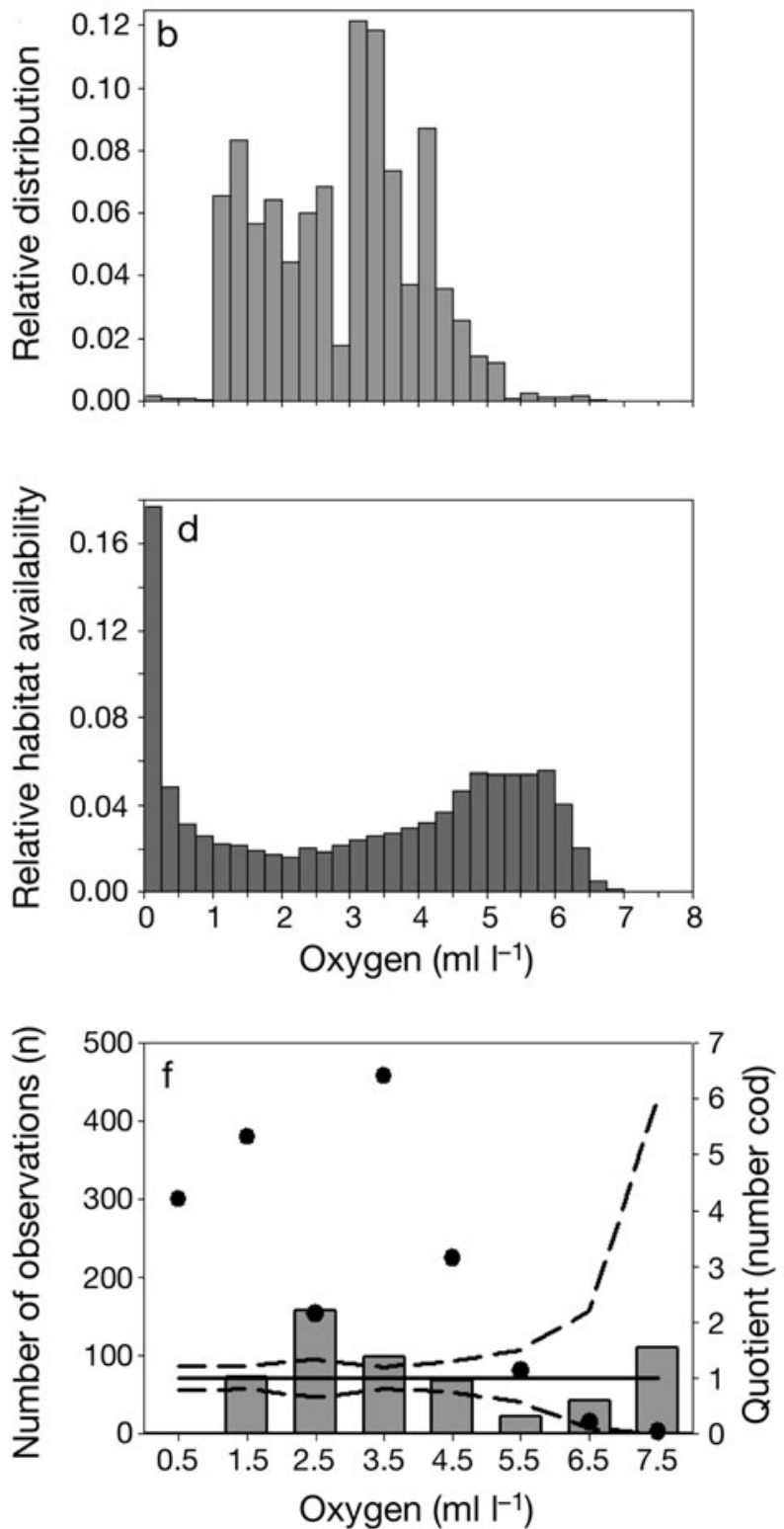

Fig. 6. Gadus morhua. Distribution of echoes below the halocline in August 2003 (a,c,e; n = 1730) and July/August 2005 (b,d,f; $\mathrm{n}=5241)$ in relation to $(\mathrm{a}, \mathrm{b})$ ambient oxygen concentration and $(\mathrm{c}, \mathrm{d})$ relative availability of habitat in both years. (e,f) Quotient rule analysis; dots: number of observations of corresponding abiotic parameter; bars: cod quotient curve; dashed lines: $95 \%$ confidence interval; solid line: quotient value 1 (marking random selection of habitat) 
above. Additionally, a slightly increasing influence of salinity on cod distribution with growing salinity levels was shown. Oxygen concentrations below $1 \mathrm{ml} \mathrm{l}^{-1}$ had a significant negative effect on cod distribution.

\section{DISCUSSION}

Field-based, individual-level records of avoidance behavior at environmental limits are a necessary prerequisite for the prediction of a population's dispersal under environmental changes (e.g. Guisan \& Zimmermann 2000, Austin 2002b, Guisan \& Thuiller 2005). Distribution data collected from trawl catches often cannot be used to derive comparative small-scale spatial behavior, as the net opening is too wide and integrates too great a vertical range (Hjelm et al. 2004). Especially in highly stratified areas like the central Baltic Sea, small vertical movements of individual fish can result in massive changes in ambient hydrography experienced by the fish. The high resolution of hydroacoustics allows sampling on a much finer (vertical)
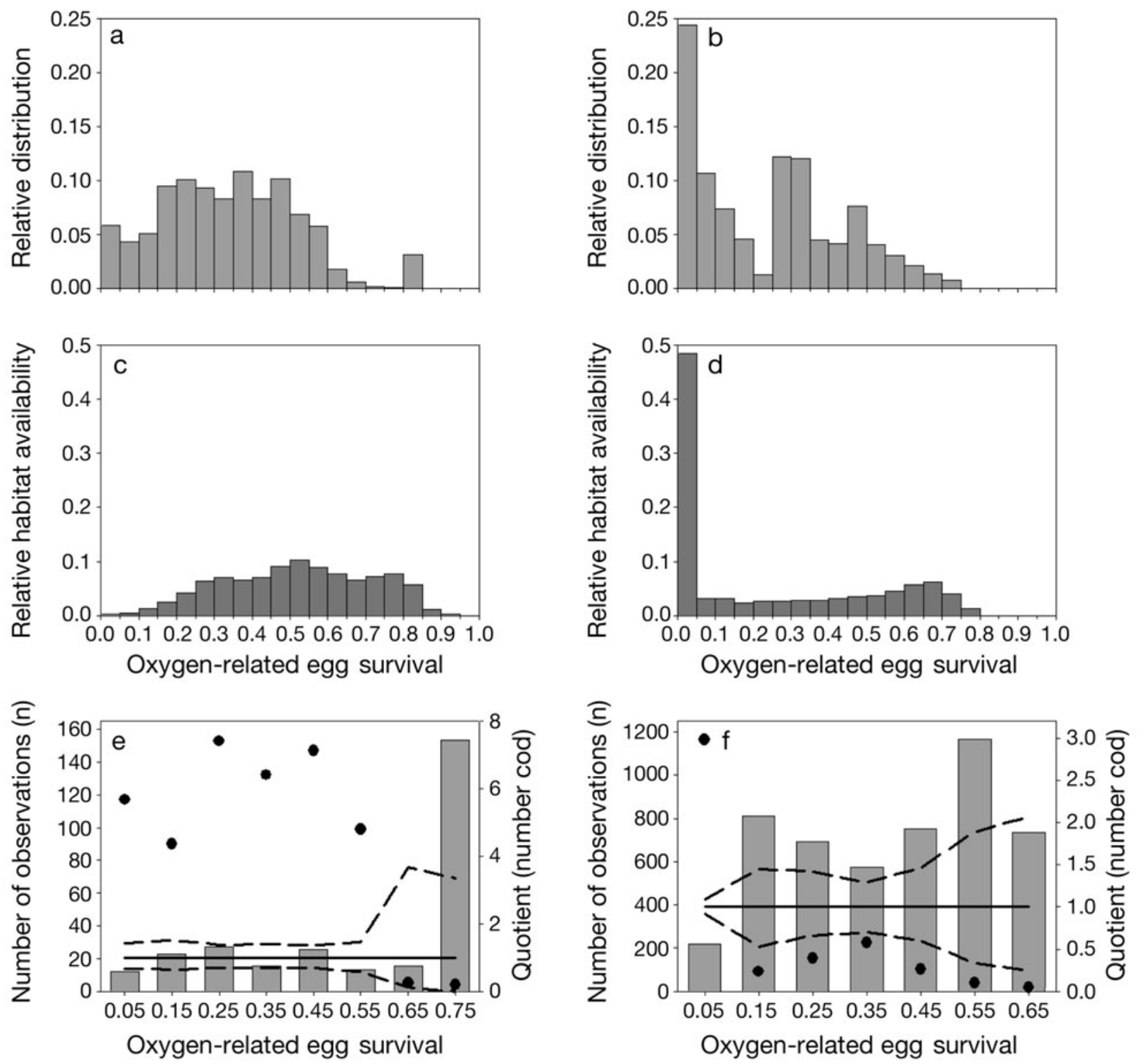

Fig. 7. Gadus morhua. Distribution of echoes within depth layers with a salinity $>11$ in August $2003(\mathrm{a}, \mathrm{c}, \mathrm{e} ; \mathrm{n}=1584)$ and July/August $2005\left(\mathrm{~b}, \mathrm{~d}, \mathrm{f}_{i} \mathrm{n}=5089\right)$ in relation to $(\mathrm{a}, \mathrm{b})$ ambient oxygen-related egg survival (OES) and (c,d) relative availability of habitat with correspondent OES in both years. $(\mathrm{e}, \mathrm{f})$ Quotient rule analysis; dots: number of observations of corresponding abiotic parameter; bars: cod quotient curve; dotted lines: 95\% confidence interval; solid line: quotient value 1 (marking random selection of habitat) 
scale and in much higher quantities. Spatially explicit considerations can additionally improve the understanding of linkages between biological and physical processes (Mason \& Brandt 1999). A high spatial resolution can help to identify the behavior of single cod towards their environment. Simultaneously, the high number of observations allows a quantitative assessment providing a good basis for the parameterization of future modeling. The high vertical and horizontal resolution of hydroacoustics, thus, can enhance the data basis for according models (e.g. Rose \& Leggett 1990, Mason \& Brandt 1996).

The method applied to interpolate ambient physical parameters has the advantage that in conjunction with data assimilation techniques a statistical measure (error variance) is provided to merge observed with modeled data in dependence on the error variance (see Neuenfeldt et al. 2007). The resolution of hydrographic data is on a kilometer scale, whereas the hydroacoustic data analyzed are usually on a meter scale. This difference in resolution can on the one hand be related to the lack of ship time available for measuring highly resolved hydrographic data. On the other hand, our method provides interpolated data on a scale that seems to be the best and only possible trade-off between requirement and availability of highly resolved hydrographic data.

As hydroacoustic devices alone cannot discriminate between individuals of different species, threshold levels must be applied to minimize confusion with nontarget species. Due to the relatively low biodiversity of fish species in the central Baltic pelagic ecosystem (ICES 2006) and derived from catch compositions of preceding investigations, the majority of echoes recorded can be allocated to either the clupeids sprat Sprattus sprattus and herring Clupea harengus, or to cod. Catch data from corresponding fishery hauls in both years revealed that a certain proportion of fish caught from clupeid species was in the same length range as juvenile cod. Cod lengths ranged from 9 to $106 \mathrm{~cm}$. Therefore, echoes from large sprat and herring could have been misidentified as small or juvenile cod using our identification threshold of $-50 \mathrm{~dB}$ for TS measurements (Rose \& Porter 1996, McQuinn \& Winger 2003, Peltonen \& Balk 2005). The threshold nevertheless was chosen in order to cover the whole observed size spectrum of cod. Due to the manual postprocessing of the echograms and the identification of clupeid aggregations, the danger of misidentification was greatly reduced. Generally, this processing may have led to a reduction of total cod identified, as cod dwelling within dense clupeid aggregations may have been mistakenly removed from the 'tracking.' However, this bias towards the identification of fewer cod nevertheless guarantees the reliability of the identified cod tracks and their ambient hydrography. Additionally, single fish echoes that were identified above the halocline could be regarded as originating from clupeids, as corresponding fishery hauls and contemporary DST recordings revealed that there were no cod distributed in these layers.

Since the target tracking algorithm in Echoview is designed to avoid including multiple targets, the detected targets are, in general, within layers that have relatively low numerical densities, i.e. cod aggregations with higher numerical density may not give a higher number of resolvable individual targets. As a result, the vertical distribution based on target tracking could provide a biased picture of the cod vertical distribution. However, a comparison of the depth distribution of identified cod echoes to the total echo (nautical area scattering coefficient, NASC) depth distribution showed a consistency of both distributions, i.e. the peak cod abundances below the halocline were consistent with peak scattering values in the echograms.

The vertical distribution of cod during the peak spawning period was controlled by salinity and oxygen concentration while an effect of temperature on vertical cod distribution was not obvious. This is probably not surprising. Although temperature is the single most important factor determining metabolic rates, the range of available temperatures during the spawning period did not include previously reported critical limits for cod (North Sea data; Sartoris et al. 2003, Lannig et al. 2004).

In both years observed, cod avoided salinities less than 11 ppt. Non-spawning cod live in a wide salinity range in the largest parts of the Baltic Sea except for the Bothnian Bay and the easternmost parts of the Gulf of Finland (Aro 1989, 2000). Cod exposed to ambient salinities of 7 ppt during experiments did not experience severe osmoregulatory disturbances (Dutil et al. 1992). Additionally, Claireaux \& Dutil (1992) showed no negative effects of acclimation of cod from salinity levels of 28 to $7 \mathrm{ppt}$ on their ability to tolerate low oxygen levels. During spawning time, adult cod prefer salinities of 11 to $15 \mathrm{ppt}$, with their distribution generally showing positive correlations to increasing salinity and oxygen levels (Tomkiewicz et al. 1998).

In 2005, a distinct oxygen depletion zone in deeper water layers marked the lower distributional boundary of cod. In contrast, ambient water was well oxygenated throughout the whole water column in 2003. Cod were consequently distributed throughout the whole column below the halocline. However, even under the hypoxic conditions in 2005, a small proportion of cod was found in regions with a corresponding oxygen saturation of less than $17 \%$. This behavior has already been observed under laboratory conditions where cod gen- 
erally avoided zones of low oxygen $(<50 \%$ saturation at $5^{\circ} \mathrm{C}$ ), but voluntarily entered regions with values as low as $16 \%$ saturation for short $\left(\sim 2 \mathrm{~min}, 5^{\circ} \mathrm{C}\right)$ excursions or if food was offered (Claireaux et al. 1995). Furthermore, data from DSTs showed that tagged cod entered oxygen-depleted layers for short periods (Neuenfeldt et al. 2009). This behavior can be related to feeding excursions. Sprat and herring are the main prey organisms of adult cod in the Bornholm Basin (Bagge 1989, Bagge et al. 1994) and obviously tolerate lower oxygen concentrations than cod $\left(>0.5 \mathrm{ml} \mathrm{l}^{-1}\right.$ and $1.0 \mathrm{ml} \mathrm{l}^{-1}$, respectively; Orlowski 2005, Stepputtis 2006). In our data, the presence of clupeid schools on echograms and in corresponding fishery hauls in the respective depths indicates that the cod could have entered the low oxygen levels for short feeding excursions.

Comparison of echorecordings and DST recordings revealed similar distribution patterns with maximal frequencies in the same depth ranges in 2005. In 2003, echorecordings of cod were found in a broader depth spectrum than tagged cod. Echo tracks were rather randomly distributed below the halocline, whereas tag data were most abundant between 60 and 75 m. Keeping in mind that the lower, oxygen determined, distributional boundaries were consistent, the advantage of acoustic data for the purpose of monitoring population dispersal while still accounting for individual limitations becomes evident: an order of magnitude more fish tracks from hydroacoustic data were available compared to the sample size from DSTs. The hydroacoustically derived data covered a much larger fraction of the distribution area of the corresponding cod population. The common distributional boundaries underline the viability of the echotracking.

The ambient habitat limits derived by the quotient plot analysis were validated by constructing a GAM. Even when accounting for further significant abiotic parameters such as position within sampling area or depth, the model only accounted for $47.7 \%$ of the total variability. This can be explained by a large value range of the corresponding input variables. Further, behavioral traits of individuals or aggregations towards other factors (e.g. food availability, spawning behavior) could not be taken into consideration in the model. Nevertheless, the results showed that supplemental to the ability to identify limiting factors on cod distribution, the behavior of cod towards these factors under different scenarios has the potential to be modeled in the future.

Cod distribution in relation to crucial ambient abiotic parameters revealed by real-time in situ echorecording can enhance the datasets provided by DSTs, especially when it comes to the scaling of DST-derived data to population level. DST-based geolocation models use data from individuals for scaling results to the population level (Neuenfeldt et al. 2007), whereas echorecordings represent a direct measure of the population characteristics.

Besides using single environmental parameters such as salinity, we also related individual vertical behavior to OES, which is a compound parameter that is difficult to integrate in experimental designs. Such compound environmental factors such as feeding success, competition, and predation risk from larger predators (Grønkjær \& Wieland 1997, Porter et al. 2005, Casini et al. 2006, Neuenfeldt \& Beyer 2006) can effectively be tested only in the field, and echotracking appears to be a useful avenue to follow for adult fish, ultimately improving our perception of the variability in essential habitats.

Acknowledgements. We thank all people involved in sampling and analyzing the data, especially Dr. D. Stepputtis. The study was carried out with financial support from the Commission of the European Communities, Agriculture, and Fisheries (FAIR), Specific Targeted Research Projects 513670 (PROTECT), and 022717 (UNCOVER) and was partly funded by REX-I (Danish Ministry of Food, Agriculture, and Fishery). This paper does not necessarily reflect the view of the commission.

\section{LITERATURE CITED}

Apostolaki P, Milner-Gulland EJ, McAllister MK, Kirkwood GP (2002) Modelling the effects of establishing a marine reserve for mobile fish species. Can J Fish Aquat Sci 59: 405-415

Aro E (1989) A review of fish migration patterns in the Baltic. Rapp PV Reun Cons Int Explor Mer 190:72-96

Aro E (2000) The spatial and temporal distribution patterns of cod (Gadus morhua callarias) in the Baltic Sea and their dependence on environmental variability - implications for fishery management. PhD thesis, University of Helsinki

Austin HM (2002a) Decadal oscillations and regime shifts, a characterization of the Chesapeake Bay marine climate. Am Fish Soc Symp 32:155-170

> Austin MP (2002b) Spatial prediction of species distribution: an interface between ecological theory and statistical modelling. Ecol Model 157:101-118

Bagge O (1989) A review of investigations of the predation of cod in the Baltic. Rapp P-V Reun Cons Int Explor Mer 190:51-56

Bagge O, Thurow F, Steffensen E, Bay J (1994) The Baltic cod. Dana 10:1-28

Bretherton FP, Davis RE, Fandry CB (1976) A technique for objective analysis and design of oceanographic experiments applied to MODE-73. Deep Sea Res I 23:559-582

> Casini M, Cardinale M, Hjelm J (2006) Inter-annual variation in herring, Clupea harengus, and sprat, Sprattus sprattus, condition in the central Baltic Sea: What gives the tune? Oikos 112:638-650

Claireaux G, Dutil JD (1992) Physiological response of the Atlantic cod Gadus morhua to hypoxia at various environmental salinities. J Exp Biol 163:97-118

Claireaux G, Webber DM, Kerr SR, Boutilier RG (1995) Physiology and behavior of free-swimming Atlantic cod (Gadus 
morhua) facing fluctuating salinity and oxygen conditions. J Exp Biol 198:61-69

Clay A, Castonguay M (1996) In situ target strengths of Atlantic cod (Gadus morhua) and Atlantic mackerel (Scomber scombrus) in the Northwest Atlantic. Can J Fish Aquat Sci 53:87-98

> Dingsør GE, Cianelli L, Chan KS, Ottersen G, Stenseth NC (2007) Density dependence and density independence during early life stages of four marine fish stocks. Ecology 88:625-634

Dutil JD, Munro J, Audet C, Besner M (1992) Seasonal variations in the physiological response of the Atlantic cod Gadus morhua to low salinity. Can J Fish Aquat Sci 49: 1149-1156

Ehrenberg JE, Torkelson TC (1996) Application of dual-beam and split-beam target tracking in fisheries acoustics. ICES J Mar Sci 53:329-334

Ferno A, Pitcher TJ, Melle W, Nottestad L, Mackinson S, Hollingworth C, Misund OA (1998) The challenge of the herring in the Norwegian Sea: making optimal collective spatial decisions. Sarsia 83(2):149-167

Fonselius S, Valderrama J (2003) One hundred years of hydrographic measurements in the Baltic Sea. J Sea Res 49:229-241

Foote KG (1987) Fish target strengths for use in echo integrator surveys. J Acoust Soc Am 82:981-987

Foote KG, Aglen A, Nakken O (1986) Measurement of fish target strength with a split-beam echosounder. J Acoust Soc Am 80:612-621

Fréon P, Gerlotto F, Soria M (1996) Diel variability of school structure with special reference to transition periods. ICES J Mar Sci 53:459-464

Grønkjær P, Wieland K (1997) Ontogenetic and environmental effects on vertical distribution of cod larvae in the Bornholm Basin, Baltic Sea. Mar Ecol Prog Ser 154:91-105

Guisan A, Thuiller W (2005) Predicting species distribution: offering more than simple habitat models. Ecol Lett 8: 993-1009

> Guisan A, Zimmermann E (2000) Predictive habitat distribution models in ecology. Ecol Model 135:147-186

> Handegard NO, Tjøstheim D (2005) When fish meet a trawling vessel: examining the behaviour of gadoids using a free-floating buoy and acoustic split-beam tracking. Can J Fish Aquat Sci 62:2409-2422

> Hinrichsen HH, Möllmann C, Voss R, Köster F, Kornilovs G (2002) Biophysical modeling of larval Baltic cod (Gadus morhua) growth and survival. Can J Fish Aquat Sci 59: 1858-1873

Hinrichsen HH, Voss R, Wieland K, Köster F, Andersen KH, Margonski P (2007) Spatial and temporal heterogeneity of the cod spawning environment in the Bornholm Basin, Baltic Sea. Mar Ecol Prog Ser 345:245-254

Hjelm J, Simonsson J, Cardinale M (2004) Spatial distribution of cod in the Baltic Sea in relation to abiotic factors a question of fish-age and area. ICES CM L:16

ICES (International Council for the Exploration of the Sea) (2001) ANNEX 2 - Manual for the Baltic international acoustic surveys (BIAS). ICES CM H:02

ICES (2006) Report of the Study Group on Multispecies Assessment in the Baltic (SGMAB). ICES CM BCC:07

Kaartvedt S, Røstad A, Fiksen Ø, Melle W, Torgersen T, Tiseth Breien M, Klevjer TA (2005) Piscivorous fish patrol krill swarms. Mar Ecol Prog Ser 299:1-5

Kändler R (1944) Untersuchungen über den Ostseedorsch während der Forschungsfahrten mit dem RFD 'Poseidon' in den Jahren 1925-1938. Ber Dtsch Wiss Komm Meeresforsch NF 11:137-245
Köster FW, Möllmann C, Hinrichsen HH, Wieland K and others (2005) Baltic cod recruitment-the impact of climate variability on key processes. ICES J Mar Sci 62:1408-1425

> Lannig G, Bock C, Sartoris FJ, Pörtner HO (2004) Oxygen limitation of thermal tolerance in cod, Gadus morhua L., studied by magnetic resonance imaging and on-line venous oxygen monitoring. Am J Physiol Regul Integr Comp Physiol 287:R902-R910

Lawson GL, Rose GA (2000a) Seasonal distribution and movements of coastal cod (Gadus morhua L.) in Placentia Bay, Newfoundland. Fish Res 49:61-75

Lawson GL, Rose GA (2000b) Small-scale spatial and temporal patterns in spawning of Atlantic cod (Gadus morhua) in coastal Newfoundland waters. Can J Fish Aquat Sci 57: 1011-1024

> Lehmann A (1995) A three-dimensional baroclinic eddyresolving model of the Baltic Sea. Tellus 47:1013-1031

Lozán JL, Kausch H (1998) Angewandte Statistik für Naturwissenschaftler. Parey, Berlin

MacLennan DN, Simmonds EJ (1992) Fisheries acoustics. Chapman and Hall, London

Mason DM, Brandt SB (1996) Effects of spatial scale and foraging efficiency on the predictions made by spatiallyexplicit models of fish growth rate potential. Environ Biol Fishes 45:283-296

Mason DM, Brandt SB (1999) Space, time, and scale: new perspectives in fish ecology and management. Can J Fish Aquat Sci 56 (Suppl 1):1-3

> Massé J, Gerlotto F (2003) Foreword. Introducing nature in fisheries research: the use of underwater acoustics for an ecosystem approach of fish population. Aquat Living Resour 16:107-112

Matthäus W, Franck H (1992) Characteristics of major Baltic inflows - a statistical analysis. Cont Shelf Res 12: 1375-1400

> Matthäus W, Schinke H (1994) Mean atmospheric circulation patterns associated with major Baltic inflows. Dtsch Hydrogr Z 46:321-339

> McKinstry CA, Simmons MA, Simmons CS, Johnson RL (2005) Statistical assessment of fish behavior from splitbeam hydro-acoustic sampling. Fish Res 72:29-44

McQuinn IH, Winger PD (2003) Tilt angle and target strength: target tracking of Atlantic cod (Gadus morhua) during trawling. ICES J Mar Sci 60:575-583

Morgan CA, De Robertis A, Zabel RW (2005) Columbia River plume fronts. I. Hydrography, zooplankton distribution, and community composition. Mar Ecol Prog Ser 299:19-31

> Morris L, Ball D (2006) Habitat suitability modeling of economically important fish species with commercial fisheries data. ICES J Mar Sci 63:1590-1603

Neuenfeldt S (2002) The influence of oxygen saturation on the distributional overlap of predator (cod, Gadus morhua) and prey (herring, Clupea harengus) in the Bornholm Basin of the Baltic Sea. Fish Oceanogr 11:11-17

> Neuenfeldt S, Beyer JE (2003) Oxygen and salinity characteristics of predator-prey distributional overlaps shown by predatory Baltic cod during spawning. J Fish Biol 62: 168-183

Neuenfeldt S, Beyer JE (2006) Environmentally driven predator-prey overlaps determine the aggregate diet of the cod Gadus morhua in the Baltic Sea. Mar Ecol Prog Ser 310: 151-163

> Neuenfeldt S, Hinrichsen HH, Nielsen A, Andersen KH (2007) Reconstructing migrations of individual cod (Gadus morhua L.) in the Baltic Sea by using electronic data storage tags. Fish Oceanogr 16:526-535

Neuenfeldt S, Anderson KH, Hinrichsen HH (2009) Some 
Atlantic cod Gadus morhua L. in the Baltic Sea visit hypoxic water briefly but often. J Fish Biol (in press)

Nilsson LAF, Thygesen UH, Lundgren B, Nielsen BF, Nielsen JR, Beyer JE (2003) Vertical migration and dispersion of sprat (Sprattus sprattus) and herring (Clupea harengus) schools at dusk in the Baltic Sea. Aquat Living Resour $16: 317-324$

Orlowski A (1999) Acoustic studies of spatial gradients in the Baltic: implications for fish distribution. ICES J Mar Sci 56:561-570

Orlowski A (2005) Experimental verification of the acoustic characteristics of the clupeoid diel cycle in the Baltic. ICES J Mar Sci 62:1180-1190

Peltonen H, Balk H (2005) The acoustic target strength of herring (Clupea harengus L.) in the northern Baltic Sea. ICES J Mar Sci 62:803-808

Porter SM, Ciannelli L, Hillgruber N, Bailey KM, Chan KS, Canino MF, Haldorson LJ (2005) Environmental factors influencing larval walleye pollock Theragra chalcogramma feeding in Alaskan waters. Mar Ecol Prog Ser 302:207-217

Robichaud D, Rose GA (2001) Multiyear homing of Atlantic cod to a spawning ground. Can J Fish Aquat Sci 58: $2325-2329$

Rose GA, Leggett WC (1990) The importance of scale to predator-prey spatial correlations: an example of Atlantic fishes. Ecology 71:33-43

Rose GA, Porter DR (1996) Target-strength studies on Atlantic cod (Gadus morhua) in Newfoundland waters. ICES J Mar Sci 53:259-265

Sartoris FJ, Bock C, Serendero I, Lannig G, Pörtner HO (2003) Temperature-dependent changes in energy metabolism, intracellular $\mathrm{pH}$ and blood oxygen tension in the Atlantic cod. J Fish Biol 62:1239-1253

Stepputtis D (2006) Distribution patterns of Baltic sprat (Sprat-

Editorial responsibility: Nick Tolimieri,

Seattle, Virginia, USA tus sprattus L.) - causes and consequences. PhD thesis, University of Kiel

Tomkiewicz J, Lehmann KM, St. John MA (1998) Oceanographic influences on the distribution of Baltic cod, Gadus morhua, during spawning in the Bornholm Basin of the Baltic Sea. Fish Oceanogr 7:48-62

- Towler RH, Jech JM, Horne JK (2003) Visualizing fish movement, behavior, and acoustic backscatter. Aquat Living Resour 16:277-282

van der Lingen $C D$, Hutchings L, Merkle D, van der Westhuizen JJ, Nelson J (2001) Comparative spawning habitats of anchovy (Engraulis capensis) and sardine (Sardinops sagax) in the southern Benguela upwelling ecosystem. In: Kruse GH, Bez N, Booth T, Dorn M and others (eds) Spatial processes and management of marine populations. University of Alaska Sea Grant, Fairbanks, AK, p 185-209

Westin L, Nissling A (1991) Effects of salinity on spermatozoa motility, percentage of fertilized eggs and egg development of Baltic cod (Gadus morhua), and implications for cod stock fluctuations in the Baltic. Mar Biol 108:5-9

Wieland K, Jarre-Teichmann A (1997) Prediction of vertical distribution and ambient development temperature of Baltic cod, Gadus morhua L., eggs. Fish Oceanogr 6: 172-187

Wieland K, Waller U, Schnack D (1994) Development of Baltic cod eggs at different levels of temperature and oxygen content. Dana 10:163-177

Wieland K, Jarre-Teichmann A, Horbowa K (2000) Changes in the timing of spawning of Baltic cod: possible causes and implications for recruitment. ICES J Mar Sci 57: $452-464$

> Wood SJR (2000) Modelling and smoothing parameter estimation with multiple quadratic penalties. J R Stat Soc B 62:413-428

Submitted: March 5, 2008; Accepted: November 12, 2008 Proofs received from author(s): February 9, 2009 